\title{
Correlation between Strategy of Tahfiz Learning Styles and Students Performance in Al-Qur'an Memorization (Hifz)
}

\author{
Azmil Hashim \\ Sultan Idris University of Education \\ azmil@fsk.upsi.edu.my
}

\author{
Doi:10.5901/mjss.2015.v6n2s5p85
}

\begin{abstract}
The aim of this study is to review strategies of tahfiz learning styles in Tahfiz Institutions in Malaysia. The study involved a total of 212 students who studied in Diploma of Tahfiz Darul Qur'an, JAKIM. The questionnaire instruments were developed by researcher and its content has been validated by panel of experts. Cronbach's alpha reliability level of value for all parts of the questionnaire was high (> 0. 9). Research data was analyzed descriptively and inferential by using the mean, standard deviation, percentage, T-test and Pearson correlation. The findings show that the strategies of tahfiz al-Qur'an learning styles were at moderately high level. Inferential data analysis found significant differences between 'gender' and 'location of tahfiz institutions' and strategies of students learning styles. The findings also show strong significant relationship between strategies of tahfiz learning styles and students performance in memorization (hafazan). Research implications conclude that elements of strategy in tahfiz learning styles should be given special attention by all parties when drafting a curriculum for tahfiz teaching and learning so that the excellence in quality of the students can be achieved.
\end{abstract}

Keywords: Learning strategies, learning styles, tahfiz learning

\section{Introduction}

Tahfiz al-Qur'an education is the earliest education in the history of Islamic education. Memorization is also a method used by the Prophet PBUH (Peace Be Upon Him) to teach the Qur'an to his Companions (Al-Habash, 1987). Allah the Most High and Exalted has makes it easy for people to memorize the Qur'an (al-Qamar 54: 17) and preserves its contents so that the Qur'an is protected from all forms of abuse and changes (al-Hijr 15: 9). Memorising the Qur'an is an effort to prevent a loss amount of people to memorize the Qur'an and it is impossible they deny al-Qur'an (mutawatir alQur'an) and also avoid any attempt to distort and falsify the Qur'an (Al-Suyuti, 1987). Allah praises and appreciates those who memorized the Qur'an with honour and noble titles such as God's chosen (Fatir 35: 32), those who have been given knowledge (al-Ankabut 29: 45) and the guardians of the authenticity of Qur'an (al-Hijr 15: 9).

\section{Research Background}

The development of tahfiz education in Malaysia, in most states move according to its own direction with the emergence of private and local tahfiz schools. Consequently, each state or tahfiz administers are free to adopt any curriculum or teaching methods from whichever country and according to educational backgrounds of individual teachers concerned (Azmil Hashim, 2010). This encourages tahfiz teachers to teach based on their own experiences and not a specific teaching method. Therefore tahfiz education systems which exist are not following any specific and systematic teaching methods (Wan Muhammad, 1995).

The factors that have been identified as a source of weakness in the performance of tahfiz are the weaknesses in teaching and learning methods of the tahfiz, i. e. the teachers still retain traditional methods of teaching and learning process in tahfiz (Mohamad Marzuq 2008; Azmil Hashim et al. , 2014) although they agree with confidence that the use of technology is helping to improve the quality of memorizing the Qur'an (Mohamad Marzuq 2008).

Weaknesses in students' performance in memorizing the Qur'an are also identified. It is due to discrepancy in strategies of tahfiz learning style i. e. students do not have proper strategy, methodology and motivation in learning tahfiz (Misnan and Ahmad Dadi, 2003; Azmil Hashim, 2010). Structured teaching and learning process for tahfiz could not be implemented properly because professional teaching skill program offer by educational institutions does not make much contribution towards tahfiz professional teaching skills (Azmil Hashim et al. , 2013). 


\section{Research Questions}

These studies generally aim to review tahfiz al-Qur'an learning styles that had been practiced by tahfiz students. Hence, the research questions are:

i. What are the strategies in tahfiz the Qur'an students' learning styles?

ii. Are there differences in strategies of tahfiz al-Qur'an learning styles by gender?

iii. Are there differences in strategies of tahfiz al-Qur'an learning styles by locality of tahfiz institutions?

iv. Is there a significant correlation between strategies of tahfiz al-Qur'an learning styles and students' performance in memorizing the Qur'an?

\section{Research Hypothesis}

This study has the following hypotheses:

$\mathrm{H}_{1}$. There is no difference in strategies of tahfiz al-Qur'an learning styles by gender.

$\mathrm{H}_{2}$. There is no difference in strategies of tahfiz al-Qur'an learning styles by locality.

$\mathrm{H}_{3}$. There is no significant correlation between strategies of learning styles and students' performance in memorizing the Qur'an.

\section{Research Methodology}

This research is a quantitative study using questionnaire and is compatible with the survey method (Robson, 1988). The questionnaire used is selected questionnaire responses. In this study the researchers chose to use the method of data collection by five items Likert scale responses types, as a scale of respondent's answers to all items used in this research instrument. Likert scale is suitable for measuring the views expressed by respondents in a particular area on an ongoing basis about a practice perceptions and attitudes (Cohen L, Manion L \& Morrison K. , 2000). In this research instrument, respondents were asked to rate an item by marking one of the numbers from 1 to 5 , based on description for each number, i. e. Strongly Disagree (1) to Strongly Agree (5).

In order to determine its validity, the questionnaires were referred to nine people who have expertise and experience in their respective fields consisting of expertise in the field of tahfiz education, Qur'anic education and research. As for the reliability of the items in the questionnaire, an analysis of the data was performed to obtain Cronbach's alpha values. It was found that the students' questionnaire instrument has a high reliability, i. e. Cronbach's alpha value of 0.96 as shown in Table 1 below:

Table 1. Classification of Reliability Index

\begin{tabular}{cc}
\hline Indicator & Alpha Cronbach's value \\
\hline Very High & $0.90-1.00$ \\
High & $0.70-0.89$ \\
Moderate & $0.30-0.69$ \\
Low & $0.00-0.30$ \\
\hline
\end{tabular}

Source: Brymen \& Cramer (1999)

The study was conducted at 11 Maahad and Tahfiz institutes across the country which implements Tahfiz Darul Qur'an, Department of Islamic Development Malaysia (JAKIM) curriculum. A total of 212 students were chosen as respondents for the study consisted of sixth semester student at Darul Qur'an, JAKIM and State Maahad Tahfiz Al-Qur'an (MTQN).

\section{Research Analysis}

The process of analyzing quantitative data was done descriptively through computerized analysis using Statistical Package for Social Sciences Version 12. 0 software. Descriptive statistics used were frequency, percentage, mean and standard deviation. Researcher describes this descriptive analysis using interpretation tables mean affective behaviours that have been formulated by Nunally (1978) as shown in Table 2. The interpretation of the mean is arranged by descending order from the highest mean to the lowest mean. 
Table 2. Interpretations Mean of Affective Behavioural Dimensions

\begin{tabular}{cc}
\hline Mean Score & Interpretation \\
\hline $4.01-5.00$ & High \\
$3.01-4.00$ & Moderate High \\
2. $01-3.00$ & Moderate Low \\
1. $01-2.00$ & Low \\
\hline
\end{tabular}

Source: Stufflebeam (1971)

Inferential statistical data analysis methods are used to obtain statistical inference from a sample of the total population. Independent-Samples T-Test procedure is used to test the significance level comparison of the mean for independent variables such as gender (male and female) and the location of the institution (DQ and MTQN). Correlation coefficient using Bivariate Correlations procedure to measure the strength of the correlation between the dependent variable is used. In this case, the Pearson correlation model was used because of the dependent variables was tested using the scale interval (Davies, 1971) as shown in Table 3.

Table 3. The Correlation Coefficient Value

\begin{tabular}{cc}
\hline The Correlation Coefficient Value $(\mathbf{r})$ & Interpretation of Coefficients \\
\hline 1.00 & Perfect \\
$0.70-0.99$ & Very high \\
$0.50-0.69$ & Strong (Substantial) \\
$0.30-0.49$ & Moderate \\
$0.10-0.29$ & Low \\
$0.01-0.09$ & Negligible \\
\hline
\end{tabular}

Source: Davies (1971)

\section{Research Findings}

\subsection{Strategies in Tahfiz Al-Qur'an Learning Styles}

Teaching strategies of tahfiz al-Qur'an were obtained through questionnaires among the students of tahfiz. Table 4 below shows the mean, standard deviation, frequency, percentage and interpretation of mean (score) of tahfiz al-Qur'an teaching and learning strategies according to students' perceptions. The findings show that eight (8) items record interpretation of mean at a high level, eight (8) items record interpretation of mean at moderate level and only one item which record interpretation of mean at a moderately low level.

Eight items recorded the interpretation of mean at a high level is checking (tasmic) new (jadid) memorization by Syafawi (orally) item (mean=4. $74, \mathrm{sd}=0.57$ ) with the percentage of very frequent and frequent at $97.7 \%$, improving the interest in memorizing the Qur'an item (mean=4. 69, $s d=0.55$ ) with the percentage of very frequent and frequent is 98 . $6 \%$, supplicate prayer item (mean $=4.55, \mathrm{sd}=0.68$ ) with the percentage of very frequent and frequent is $93.6 \%$, learn the importance of memorizing (the Qur'an) (mean=4. 54, sd=0. 63), sincerity of intention item (mean=4. 47, sd=0. 72) with percentages of very frequent and frequent is $92.6 \%$, seeking for forgiveness item (mean=4. 38, sd=0. 82) with the percentage of very frequent and frequent is $90.4 \%$, learn the advantages of memorizing item (mean $=4.30, s d=0.61$ ) with the percentage of very frequent and frequent is $97.7 \%$, and revising previous (qodim) memorization by Syafawi (orally) item (mean $=4.30, \mathrm{sd}=0.91$ ) with the percentage of very frequent and frequent is $84 \%$.

While items that have interpretation mean at a moderate-high is complete memorization (murajacah majmuc) item according to schedule (mean=3. $81, \mathrm{sd}=1.18$ ) with the percentage of very frequent and frequent is $68.8 \%$, record new (jadid) memorization item (mean=3. $50, \mathrm{sd}=1.34$ ) with the percentage of very frequent and frequent at $53.7 \%$, has a specific schedule for revision item (mean $=3.42, \mathrm{sd}=1.05$ ) with the percentage of very frequent and frequent is $49 \%$, enhancing the motivation item (mean=3. $25, \mathrm{sd}=1.29$ ) with the percentage of very frequent and frequent is $44 \%$, steadfast in memorization revision item (mean=3. 33, sd=1. 01) with the percentage of very frequent and frequent is 41. $7 \%$, disciplined in following the revision schedule item (mean=3. $21, \mathrm{sd}=0.97$ ) with the percentage very frequent and frequent at $35.3 \%$, record old memorization item (mean $=3.05, \mathrm{sd}=1.34$ ) with the percentage of very frequent and 
frequent is $37.6 \%$, and tested new (jadid) memorization by writing (tahriri) item (mean=3. $01, \mathrm{sd}=1.26$ ) with the percentage of very frequent and frequent at $36.3 \%$.

Meanwhile, the item that recorded interpretation mean at a moderately low level is revising previous (qodim) memorization by writing (tahriri) ítem (mean=2. 90, sd=1. 18) with the percentage of very frequent and frequent only 29. $8 \%$.

Based on the research findings, this study show that the learning strategies of tahfiz al-Qur'an preferred by students are checking (tasmic) new (jadid) memorization by Syafawi (orally), improving the interest in memorizing the Qur'an, supplicate prayer before memorizing, sincere intentions, seeking forgiveness, learn the advantages of memorizing the Qur'an, and revising previous (qodim) memorization by Syafawi (orally).

The study also found that the tahfiz Qur'an learning strategies which is given less attention by students are complete memorization (murajacah majmuc) according to schedule, record the new (jadid) memorization, has a specific schedule for revision, enhance motivation, steadfast in memorization revision, discipline in following the revision schedule, record previous memorization (qadim) and tested new (jadid) memorization by writing (tahriri). While, the practice with the least attention by students is revising previous (qodim) memorization by writing (tahriri).

Table 4. Tahfiz Learning Styles Strategies

\begin{tabular}{|l|ccc|}
\hline Strategy & Mean & S. D & Interpretation \\
\hline New (jadid) memorization by Syafawi (orally) & 4.74 & 0.57 & High \\
Improving the interest in memorizing the Qur'an & 4.69 & 0.55 & High \\
Supplicate prayer & 4.55 & 0.68 & High \\
Learn the importance of memorizing (the Qur'an) & 4.54 & 0.63 & High \\
Sincerity of intention & 4.47 & 0.72 & High \\
Seeking for forgiveness & 4.38 & 0.82 & High \\
Learn the advantages of memorizing (the Qur'an) & 4.30 & 0.61 & High \\
Revising old (qodim) memorization by Syafawi (orally) & 4.30 & 0.91 & High \\
Complete memorization (murajacah majmuc) according to schedule & 3.81 & 1.18 & Moderately High \\
Record the new (jadid) memorization & 3.50 & 1.34 & Moderately High \\
Has a specific schedule for revision (memorization) & 3.42 & 1.05 & Moderately High \\
Steadfast in memorization revision & 3.33 & 1.01 & Moderately High \\
Enhancing the motivation & 3.25 & 1.29 & Moderately High \\
Disciplined in following the revision schedule & 3.21 & 0.97 & Moderately High \\
Record previous memorization (qodim) & 3.05 & 1.34 & Moderately High \\
Tested new (jadid) memorization by writing (tahriri) & 3.01 & 1.26 & Moderately High \\
Revising previous (qodim) memorization by writing (tahriri) & 2.90 & 1.18 & Moderately Low \\
Total Mean & 3.94 & $\mathbf{0 . 4 3}$ & Moderately High \\
\hline
\end{tabular}

\subsection{Differences in Strategies of Tahfiz al-Qur'an Learning Style by Gender Demographics}

Ho1 There is no significant difference between mean scores in strategies of tahfiz students learning style by gender demographics.

The research finding from one-way Analysis of Variance to examine the mean score in strategies of tahfiz alQur'an students learning style based on the gender demographics.

Table 5. T-test Differences in Strategies of Tahfiz Learning Style by Gender Demographics

\begin{tabular}{c|ccccc}
\hline Sex & $\boldsymbol{N}$ & Mean & SD & t-value & Sig. $\boldsymbol{P}$ \\
\hline Male & 120 & 3.86 & 0.45 & -2.055 & $0.041^{*}$ \\
Female & 98 & 3.98 & 0.39 & & \\
\hline
\end{tabular}

Significant at the level of $p<0.05$

The T-test analysis results shown in Table 5 above shows significant differences in mean scores $(P=0.041, p<0.05)$ in strategies of tahfiz learning style between males (mean=3. 86, $s d=0.45$ ) and females (mean=3. 98, $p<0$. 39). With this result, $\mathrm{Ho}_{1}$ is rejected. This analysis also showed that the strategies of tahfiz learning among female respondents are higher than male respondents. 


\subsection{Differences in Strategies of Tahfiz al-Qur'an Learning Style Based on Tahfiz Institution Locality Background}

$\mathrm{Ho}_{2}$ There is no significant differences between mean scores in strategies of tahfiz students learning style based on tahfiz institution locality background.

The research finding from one-way Analysis of Variance to examine the mean score in strategies of tahfiz alQur'an students learning style based on tahfiz institution locality background.

Table 6. T-test Differences in Strategies of Tahfiz Learning Style Based on Tahfiz Institution Locality Background

\begin{tabular}{c|ccccc}
\hline Location & $\boldsymbol{N}$ & Mean & SD & T-value & Sig. $\boldsymbol{P}$ \\
\hline Darul Qur'an & 143 & 3.96 & 0.44 & 2.117 & $0.035^{\star}$ \\
MTQN & 75 & 3.83 & 0.38 & & \\
\hline
\end{tabular}

Significant at the level of $p<0.05$

The T-test analysis results as in Table 6 above shows significant differences in mean scores $(P=0.035, p<0.05)$ for strategies of tahfiz learning style between the Darul Qur'an students (mean=3. 96, sd=0. 44) and the State Maahad Tahfiz al-Qur'an students ( $\min =3.83, \mathrm{p}<0.38$ ). Hence, $\mathrm{Ho}_{2}$ is rejected. This analysis also indicates that the strategies of tahfiz learning style among students of Darul Qur'an are higher than students in the State Maahad tahfiz al-Qur'an.

\subsection{Relationship Between Strategies in Tahfiz Al-Qur'an Learning Style and Student Memorization (Hafazan) Performance Levels}

Inferential data analysis has also been carried out to identify the relationship between strategies in tahfiz al-Qur'an learning styles and students memorization (hafazan) performance. This inference analysis relationship was conducted in order to answer the third question in this study. Pearson Correlation methods were used to analyze inference relationship in this study.

$\mathrm{H}_{3}$ There is no significant correlation between strategies of learning styles and students' performance in memorizing the Qur'an.

Results of Pearson correlation analysis are to identify the relationship between learning styles and students memorization performance as shown in Table 7 below:

Table 7. Correlation Between Tahfiz Learning Styles with Student Performance Level

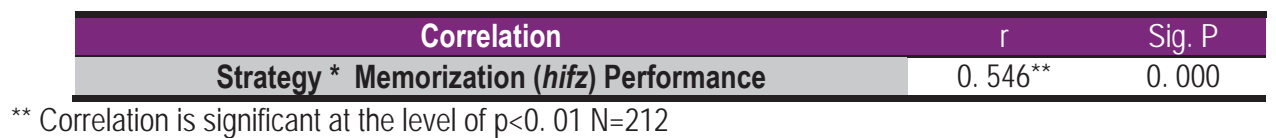

Pearson correlation analysis is to identify the relationship between strategy in tahfiz al-Qur'an learning style and student memorization performance as shown in Table 7 above. It shows that there is a strong significant relationship between strategies in learning styles and student memorization performance $(r=0.546, p<0.01)$. Thus, $\mathrm{H}_{3}$ is rejected.

\section{Discussion}

The study found that the elements of strategy show that the strategy in tahfiz al-Qur'an learning style is an incremental design, i. e. continuous in development and improvement. This is evidenced by the elements of strategy in learning styles are moderately high. Strategies in tahfiz learning styles have three elements, i. e. preparatory strategy, reinforcement strategy and retention strategy.

The research findings of preparatory strategy in tahfiz learning styles show that students were focus and pay attention to these aspects of strategy, i. e. learn the importance of memorizing (the Qur'an), improving the interest in memorizing the Qur'an, learn the advantages of memorizing (the Qur'an), sincerity of intention, seeking forgiveness and supplicate pray before memorizing the Qur'an. Nevertheless the study also shows that students were less motivate in memorizing the Qur'an. This is evident by every item of preparatory strategies in students learning styles scored a higher level, but for enhancing the motivation item its only acquire moderately high score.

This shows that tahfiz students have the passion, initiative and high self learning in tahfiz al-Qur'an learning style. 
Nevertheless in terms of motivational aspect, students feel it is not sufficient and require more guidance and improvement. The importance of motivation in tahfiz learning styles has been proved by Misnan and Ahmad Dadi (2003) by asserting that there is a high correlation between the methods of motivation and students performance in tahfiz alQur'an. Study by Azmil Hashim et al. (2014) also pointed out that higher level tahfiz learning methods can help in the performance of the Qur'an memorization because there is a significant correlation between higher level methods and the performance of the Qur'an memorization.

The findings of reinforcement strategy in tahfiz learning styles shows that the method of students recite new (jadid) memorization by syafawi (orally) is widely practiced. It is clearly indicated since this item is at a high level. Where else revising the new memorization by writing ( tahriri) and students' record their progress in a record book are not widely practiced by students. This is indicated clearly as both items are at moderate level. According to Abu Najihat (2002) and As-Syarbini (2004), in order to strengthen students' memorization, teacher should do checking memorization (tasmic) on each new (jadid) memorization orally (syafawi). Abu al-Wafa' (1999) and Abu al-Fida' (2006) also adds that tasmic new (jadid) memorizing must also be done by tahriri, i. e. by writing on paper.

The findings in memorization retention strategies in tahfiz learning styles shows that students are concerned about revising previous (qodim) memorization orally (syafawi). However, revising previous memorization in writing (tahriri) was not fully practiced by students. They are also less practiced in keeping their progress in record books. In retention strategy of tahfiz learning style, it indicates students did not complete memorization of the Qur'an (khatam) revision (murajacah majmuc) according to schedule, lack of specific schedule for hafazan revision, less disciplined and less steadfast in following the revision memorizing schedule. Retention strategies in this learning style needs to be upgrade so that retention memorization can be achieved by students. This is evidence by Mohamad Marzuq (2008) who stated that the practice of icadah i. e. tasmic qadim and murajacah majmuc significantly correlated with student memorization performance.

This has been asserted by Abu Najihat (2002) that discipline and perseverance are indispensable in revising memorization of the Qur'an, and with this the verses of the Qur'an that has been memorized remain in students' memory. Retention strategies in learning style has been affirmed by Muhammad Muhsin (1994), Abu al-Wafa (1999) and Abu Najihat (2002) by stating that in order to retain memorization, teachers are required to do tasmic of previous (qodim) memorization and revising memorization (murajacah majmuc). Mohd Farouq (1427 $\mathrm{AH}$ ) adds that at the end of each lesson, teacher should records the progress and development of students in a record book. Hence student's memorizing level can be known and this can be a guide when teachers are assessing students' performance in memorization.

\subsection{Differences in Strategies of Tahfiz Teaching Based on Gender and Location of Institution}

Overall, inferential statistical analysis showed that there are significant differences in the pattern of strategy in tahfiz alQur'an learning styles by gender and institutional location. The findings of the analysis showed that there are significant differences in strategy of learning styles between females and male students. It was found that female students have higher level strategies in learning styles than male students. This shows the use of learning strategies in tahfiz learning styles is wider among female students than male students. Generally, female students have a higher learning style than male students (Azhar Ahmad, 2006) and they are also having a higher level of commitment than male students (Rohani Arbaa, 2010). This study was consistent with the study of Azmil Hashim et al. (2014) which showed that there were significant differences in learning manners among females compare to males student. It was found that females' students have a higher learning manner than male students. While the study by Rowe (2000) and Mac Donald et al. (1999) showed that male students are less committed to school and are more likely to face the risk of low academic performance, particularly in literacy. Male students also reported having less positive school experience in terms of enjoyment in school, the benefits received through the curriculum and positive response from teachers (Rowe 2000).

There are also significant differences in strategies of learning styles based on the background or locality of the institution. It was found that the students of Darul Qur'an have better strategies in learning styles than students of MTQN. It is likely Darul Qur'an has a more structured education system that emphasizes tahfiz learning styles compared to MTQN. The different learning styles based on the background or locality of the rural versus urban institutions occurred due to urban institutions have diversity of methods compared to rural schools (Kamarul Azmi Jasmi et al. , 2011).

\section{Study Implications}

In general, this study found that, there are some weakness and shortcomings in the strategies of students learning styles which must be improved and developed. In the aspect of preparatory strategy in learning styles, it implies preparatory 
strategy requires enhancement and improvement in an effort to increase knowledge on the importance and advantages of memorizing the Qur'an (tahfiz), instil deep interest in memorizing the Qur'an, always sincere in memorizing the Qur'an, purify oneself by seeking forgiveness and pray (to Allah) to make it easier and keep steadfast in memorizing verses from the Qur'an.

While in the aspect of process strategy, it also implies guidance in memorizing methods, memorizing techniques, memorizing activities and preserved manner in memorizing the Qur'an should be enhanced. Development in educational technology should be utilised wisely to provide guidance on methods and techniques in memorizing (the Qur'an) as well as in tahfiz teaching and learning. Traditional methods of tahfiz education which is practice previously should be strengthened and enhanced by adapting into contemporary teaching and learning technologies.

Implications of reinforcement strategies aspect in tahfiz learning styles are also need to enhance and improve. In reinforcement strategies, the checking (tasmic) of new (jadid) memorization should be implemented properly. Records on the progress of students memorizing and new memorizing revision by writings (tahriri) is an important aspect in this enforcement strategy. It can determine and measure the extent of performance and ability levels of students on their memorization.

Implications for retention strategies in tahfiz learning styles also requires incremental change i. e. development and improvement. Aspects of improving discipline and steadfast in revising memorization is an attitude that needs to be improved. The practise of tasmic qodim and murajacah majmuc should be implemented in a good manner. Specific schedule for revising memorization by tasmic godim and murajacah majmuc until the entire Qur'an is fully memorized (khatam) successfully according to the schedule should be fully enforced. While checking previous memorization by writing (Tahriri) is also an important aspect of retention strategies that should not be ignored.

The findings of differences in tahfiz al-Qur'an learning styles from this study provides an understanding of gender factors that should be taken into consideration by all parties in formulating strategies for tahfiz learning styles. Thus the students may excel in their memorization especially male students. Meanwhile the locality factors should also be considered when formulating strategies for tahfiz learning styles in order to form a conducive learning climate in all tahfiz institutions due to improve the quality of students memorization performance.

Analysis of strategies in tahfiz learning style found a strong relationship between tahfiz learning styles and students' performance in memorization. It provides an understanding that the strategies in tahfiz learning styles should be given explicit emphasis, and extended in tahfiz learning style. This is because the strategy in learning style has contributed significantly to the performance of tahfiz students.

\section{Conclusion}

This study shows the strategies in tahfiz learning styles and its relationship with students' performance. The findings also indicate that the strategies in tahfiz students learning styles have a strong relationship with student's performance. Thus the elements of strategies in tahfiz learning styles should be given special attention by all parties when drafting a curriculum for tahfiz teaching and learning. Tahfiz teachers and students should be exposed to these strategies and implement them in the teaching and learning of tahfiz. This is to ensure that the students achieve an excellence quality performance in memorizing the Qur'an.

\section{References}

Al-Qur'an

Abu Al-Fida', Muhammad Izzat (2006). Kaifa nahfazul Qur'an. Kaherah: Darul Salam.

Abu Al-Wafa, Aliyallah Ali (1999). An-Nur al-mubin litahfiz al-Qur'an al-Karim. Kaherah: Darul Wafa'.

Abu Najihat Al-Hafiz (2002). Panduan bagi hafiz-hafizah dan qari dan qari'ah. Selangor. Penerbit Darul Iman.

Al-Habash, As-Syeikh Muhammad (1987). Kaifa tahfaz al-Qur'an. Beirut: Dar al-Khair.

Al-Suyuti, Jalaluddin Abdul Rahman (1987). Al-Itqan fi culumil Qur'an. Maktabah Mustafa al-Bab al-Halaby.

Azhar Ahmad. 2006. Strategi pembelajaran pengaturan kendiri pendidikan islam dan penghayatan akhlak pelajar sekolah menengah di Sarawak. Tesis Dr. Falsafah, Fakulti Pendidikan. Universiti Kebangsaan Malaysia.

Azmil Hashim (2006). Pengetahuan Al-Qur'an di Kalangan Perajurit Muda Pusat Latihan Asas Tentera Darat Port Dickson. Kertas projek Sarjana: Fakulti Pendidikan. Universiti Malaya.

Azmil Hashim (2010). Penilaian Pelaksanaan Kurikulum Tahfiz Darul Qur'an dan Maahad Tahfiz al-Qur'an Negeri. Tesis ljazah Doktor Falsafah. Universiti Kebangsaan Malaysia.

Azmil Hashim, Ab. Halim Tamuri dan Misna Jemali (2013). Latar Belakang Guru Tahfiz Dan Amalan Kaedah Pengajaran Tahfiz AlQur'an Di Malaysia. The Online Journal of Islamic Education. Vol. 1 Issue $128-39$ 
Azmil Hashim, Tamuri, H. , Noh, C. , \& Aderi, M. (2014). The Relationships between Etiquettes of Tahfiz (Memorization Al-Qur'an) and Tahfiz Achievement. Australian Journal of Basic \& Applied Sciences, 8 (23).

Brymen, A. \& Cramer, D. (1999). Quantitative data analysis with SPSS Release 8 for Windows: A guide for social scientists. London: Routledge.

Cohen, L, Manion, L \& Morrison, K. (2000). Research methods in education. London: Routledge Falmer.

Davies, I. I. C. (1971), The Management of Learning. London: C. Gain Hill.

Kamarul Azmi Jasmi, Mohd Faeez Illias, Ab Halim Tamuri, Mohd Izaham Mohd Hamzah (2011). Amalan Penggunaan Bahan Bantu Mengajar dalam kalangan Guru Cemerlang Pendidikan Islam Sekolah Menengah Malaysia. Journal of Islamic and Arabic Education. 3 (1), 2011, 59-74.

Misnan Jemali \& Ahmad Sadadi Hafidz. (2003). Hubungan antara kaedah menghafaz al-Qur'an dengan pencapaian Kursus Tahfiz wa al-Qiraat pelajar semester empat dan lima di Maahad Tahfiz wal Qiraat di Perak. Seminar Kaedah pengajaran Tahfiz al-Qur'an Peringkat Kebangsaan. Kolej Universiti Islam Malaysia.

Mohd Farouq Mohd Al-Raiy 1427H. Al-tariqah al-'amaliyyah lit'allumi wa ta'alim al-Qur'an hifzan wa tilawatan bittajwid wal itqan. Jeddah: Syirkah al-Madinatul Munawwarah litaba'ah wal-nasyr.

Mohamad Marzuqi Abd Rahim (2008). Pengajaran Mata Pelajaran Hafazan Al-Qur'an: Suatu Kajian Maahad Tahfiz Al-Qur'an Zon Tengah. Kertas Projek Sarjana: Fakulti Sains Kognitif dan Pembangunan Manusia: Universiti Pendidikan Sultan Idris.

Mohd Aderi Che Noh. 2004. Celik Al-Qur'an di kalangan Pelajar Tingkatan Satu Zon Pudu Kuala Lumpur. Projek Penyelidikan Fakulti Pendidikan. Universiti Kebangsaan Malaysia.

Muhammad Muhsin Syeikh Ahmad (1994). Al-Qur'an dan cara-cara menghafaz. Shah Alam: Perpustakaan Darul Qur'an.

Nunally, J. C. (1978). Psycometric theory. New York: Mc Graw Hill Book Company.

Robson, Collin. (1998). Real world research. UK: Blackwell Publisher Ltd.

Rohani Arbaa, Hazri Jamil \& Nordin Abd Razak. (2010). Hubungan guru-pelajar dan kaitannya dengan komitmen belajar pelajar: Adakah guru berkualiti menghasilkan perbezaan pembelajaran antara jantina pelajar? Jurnal Pendidikan Malaysia 35 (2): 61-69

Rowe, K. J. (2000). Exploring Real Effects from Evidence-based Research in Teacher and School Effectiveness. The Educational Performance Of Males And Females In School And Tertiary Education. Paper presented at Educational Attainment and Labour Market Outcomes: Factors Affecting Boys and Their Status in Relation to Girls. Melbourne, Australia.

Wan Muhammad Abdul Aziz (1995). Ke arah penyelarasan sistem pengajian tahfiz al-Qur'an di Malaysia. Jurnal Institut Pengajian Tahfiz al-Qur'an. Bil 1. 1-8. 